University of Nebraska - Lincoln

DigitalCommons@University of Nebraska - Lincoln

Faculty Publications: Department of Entomology

2008

\title{
Using Ninhydrin to Detect Gravesoil
}

David O. Carter

University of Nebraska-Lincoln, dcarter2@unl.edu

David Yellowlees

James Cook University, david.yellowlees@jcu.edu.au

Mark Tibbett

University of Western Australia, Mark.Tibbett@uwa.edu.au

Follow this and additional works at: https://digitalcommons.unl.edu/entomologyfacpub

Part of the Entomology Commons

Carter, David O.; Yellowlees, David; and Tibbett, Mark, "Using Ninhydrin to Detect Gravesoil" (2008). Faculty Publications: Department of Entomology. 189.

https://digitalcommons.unl.edu/entomologyfacpub/189

This Article is brought to you for free and open access by the Entomology, Department of at DigitalCommons@University of Nebraska - Lincoln. It has been accepted for inclusion in Faculty Publications: Department of Entomology by an authorized administrator of DigitalCommons@University of Nebraska - Lincoln. 
Published in Journal of Forensic Sciences 53:2 (2008), pp. 397-400; doi: 10.1111/j.1556-4029.2008.00681.x Copyright (C 2008 American Academy of Forensic Sciences; published by Wiley-Blackwell. Online at http://www.blackwell-synergy.com Used by permission.

This research was presented in part at the 59th Annual Meeting of the American Academy of Forensic Sciences, San Antonio, TX, Feb. $19-24,2007$.

Submitted May 21, 2007; revised September 9, 2007; accepted September 15, 2007; published online March $24,2008$.

\title{
Using Ninhydrin to Detect Gravesoil
}

\author{
David O. Carter, ${ }^{1}$ David Yellowlees, ${ }^{1}$ and Mark Tibbett ${ }^{2}$
}

${ }^{1}$ School of Pharmacy and Molecular Sciences, James Cook University, Townsville, QLD 4811, Australia
${ }^{2}$ Centre for Land Rehabilitation, School of Earth and Geographical Sciences, University of Western Australia, Crawley 6009, Australia

Corresponding author - D. O. Carter; present address: Department of Entomology, University of Nebraska-Lincoln, 202 Plant Industry Building, Lincoln, NE 68583-0816; email dcarter2@unl.edu

\begin{abstract}
Some death scene investigations commence without knowledge of the location of the body and/or decomposition site. In these cases, it is necessary to locate the remains or the site where the body decomposed prior to movement. We hypothesized that the burial of a mammalian cadaver will result in the release of ninhydrin reactive nitrogen (NRN) into associated soil and that this reaction might have potential as a tool for the identification of clandestine graves. Juvenile rat (Rattus rattus) cadavers were buried in three contrasting soil types in Australian tropical savanna ecosystems and allowed to decompose over a period of 28 days. Soils were sequentially harvested and analyzed for NRN. Cadaver burial resulted in an approximate doubling (mean =1.7 \pm 0.1 ) in the concentration of soil NRN. This reaction has great potential to be used as a presumptive test for gravesoil and this use might be greatly enhanced following more detailed research.
\end{abstract}

Keywords: forensic science, forensic taphonomy, cadaver decomposition, grave location, clandestine

Victims of fatal crime are often concealed by the perpetrator in an attempt to evade capture (1). One relatively common approach for concealing a corpse is burial in soil (2). Obviously, concealing a cadaver has a confounding effect on the search and location of these bodies and, as a result, several techniques have been developed to assist in the location of buried cadavers. These include probing (3), the use of cadaver dogs (4), geophysics (3), and the measurement of decomposition odors (5). Unfortunately, none of the methods currently used to locate clandestine graves is successful under every scenario. Thus, a need exists for the continual development of new methods for the detection of gravesoil (any soil associated with a decomposing cadaver [6]). Ideally, the location of these sites would be rapid and require little destruction of putative crime scenes, such as that achieved with cadaver dogs.

Much recent research has focused on the decomposition processes in gravesoils (7-11). This work has shown that cadaver decomposition results in a significant pulse of nitrogen $(\mathrm{N})$ into associated soil $(7,8)$, some of which is in the form of ammonium $\left(\mathrm{NH}_{4}^{+}\right)$and nitrate $\left(\mathrm{NO}_{3}{ }^{-}\right)$. This, in itself, is not surprising, as a body typically comprises approximately 3\% N (12). Knowing this, it is logical that cadaver decomposition would also result in the release of organic forms of $\mathrm{N}$, such as protein, peptide, and amino acids. These nitrogenous compounds, in addition to ammonium, represent chemicals that react with ninhydrin.

Since the description of ninhydrin in 1910 (13), the compound has found regular use in food, medical, and agricultural sciences. A forensic application for the reaction of ninhydrin with organic- and ammonium-nitrogen has been recognized since the mid-1950s (14) and ninhydrin is now regularly used as a medium to detect latent fingerprints on porous surfaces such as paper (e.g., 15). As such, ninhydrin is a compound that is readily available to most investigative agencies.

We hypothesized that the decomposition of a body would result in a significant increase in ninhydrin reactive nitrogen
(NRN) in soil. To test this hypothesis, we buried mammalian cadavers in soils located at three contrasting sites in Australian tropical savanna ecosystems. Ninhydrin reactive $\mathrm{N}$ was measured in gravesoil at 7-day intervals over a period of 28 days.

\section{Materials and Methods}

Juvenile rats (Rattus rattus) ( 20 g) were used as model cadavers in one of three contrasting sites in tropical savanna ecosystems of Queensland, Australia during the dry season (Oct. 2002). These sites were Yabulu $\left(19^{\circ} 12^{\prime} \mathrm{S}, 146^{\circ} 36^{\prime} \mathrm{E}\right)$, Pallarenda $\left(19^{\circ} 11^{\prime} \mathrm{S}, 146^{\circ} 46^{\prime} \mathrm{E}\right)$, and Wambiana (203' S, $\left.146^{\circ} 08^{\prime} \mathrm{E}\right)$. Yabulu soil was a Brown Sodosol (16) and had a loamy sand texture $(84.2 \%$ sand, $11.0 \%$ silt, $4.8 \%$ clay). Pallarenda soil was a Rudosol (16) and had a sandy texture $(97.7 \%$ sand, $1.3 \%$ silt, $1.0 \%$ clay). Wambiana soil was a Grey Vertosol (16) and had a medium clay texture $(30.9 \%$ sand, $20.8 \%$ silt, $48.3 \%$ clay). Soil chemical characteristics are presented in Table 1.

Cadavers were buried $(2.5 \mathrm{~cm})$ on their right side in the center of $2 \mathrm{~m}^{2}$ plots of soil. Control (soil without cadaver) graves were dug $2 \mathrm{~m}$ away from each cadaver. Gravesoil and control soil was sequentially and destructively sampled at 7, 14, 21, and 28 days following burial (17). Thus, cadavers were buried and exhumed only once. This harvesting regime avoided the effects of soil disturbance. This experiment was replicated six times, which resulted in the collection of 48 soil samples at each site.

Measurement of NRN in soil followed the method developed by Amato and Ladd (18). Two grams of soil (dry weight) was amended with $8 \mathrm{~mL}$ potassium chloride $(\mathrm{KCl})(2 \mathrm{M})$ and shaken $(150 \mathrm{rpm})$ for $30 \mathrm{~min}$. Following shaking, the solution was filtered through a Whatman No. 42 filter paper into a sterile test tube. To $1 \mathrm{~mL}$ of filtrate, $0.5 \mathrm{~mL}$ ninhydrin reagent (0.8 g ninhydrin [Sigma N6014], $0.12 \mathrm{~g}$ hydrindantin [Sigma H2003], $30 \mathrm{~mL}$ dimethyl sulfoxide, $10 \mathrm{~mL}$ lithium acetate) was added, mixed, and incubated at $100^{\circ} \mathrm{C}$ for $25 \mathrm{~min}$ 
Table 1. Physical, chemical, and biological characteristics of soils at Yabulu, Pallarenda, and Wambiana, Queensland, Australia.

\begin{tabular}{|c|c|c|c|}
\hline \multirow[t]{2}{*}{ Determinant } & \multicolumn{3}{|c|}{ Soil } \\
\hline & Yabulu & Pallarenda & Wambiana \\
\hline Bulk density $\left(\rho_{\mathrm{b}}\right)\left(\mathrm{mg} / \mathrm{cm}^{3}\right)$ & 1.50 & 1.40 & 1.05 \\
\hline Total porosity $(\theta)\left(\mathrm{cm}^{3} / \mathrm{cm}^{3}\right)$ & 0.40 & 0.41 & 0.55 \\
\hline$\%$ Coarse sand (2.0-0.2 mm) & 35.2 & 69.6 & 8.2 \\
\hline$\%$ Fine sand $(0.2-0.02 \mathrm{~mm})$ & 49.0 & 28.1 & 22.7 \\
\hline Soil texture & Loamy sand & Sand & Medium clay \\
\hline $\mathrm{pH}\left(\mathrm{H}_{2} \mathrm{O}\right)$ & $3.4(0.2)$ & $4.9(0.1)$ & $6.1(0.1)$ \\
\hline Total C (\%) & $1.09(0.1)$ & $1.35(0.1)$ & $1.18(0.1)$ \\
\hline Organic C (\%) & $0.84(0.0)$ & $1.30(0.1)$ & $0.99(0.0)$ \\
\hline Total N (\%) & $0.04(0.0)$ & $0.10(0.0)$ & $0.07(0.0)$ \\
\hline Total P (\%) & $0.01(0.0)$ & $0.03(0.0)$ & $0.01(0.0)$ \\
\hline Phosphodiesterase activity ( $\mu \mathrm{g}$ p-nitrophenol/g soil/h) & $7.1(0.7)$ & $13.2(1.3)$ & $25.0(2.4)$ \\
\hline
\end{tabular}

Numbers in brackets represent standard errors where $n=6$.

at the laboratory. Samples were then removed and allowed to stand at room temperature ( $20 \mathrm{~min})$. The solution was then amended with $10 \mathrm{~mL} \mathrm{50 \%} \mathrm{ethanol-water}(\mathrm{v} / \mathrm{v})$ and absorbance was read at $570 \mathrm{~nm}$ (Genesys $10 \mathrm{Vis}$ spectrophotometer, Thermo Scientific, Waltham, MA). The concentration of NRN was calculated against a leucine standard that was processed in the same manner as the soil samples. To make leucine standard, $0.469 \mathrm{~g}$ leucine was dissolved into $1 \mathrm{~L}$ distilled water. This contained $50 \mu \mathrm{g} \mathrm{N} / \mathrm{mL}$. Separate $100 \mathrm{~mL}$ volumetric flasks were amended with $0,5,10,15,20$, and $30 \mathrm{~mL}$ leucine solution, $50 \mathrm{~mL}$ of $2 \mathrm{M} \mathrm{KCl}$, and water to make up to $100 \mathrm{~mL}$. These standards contained $0,2.5,5,7.5,10$, and $15 \mu \mathrm{g} \mathrm{N} / \mathrm{mL}$.

\section{Statistical Analysis}

Data analysis was conducted using SPSS v.15. Normality and homogeneity of variance were tested using the Kolmogorov-Smirnov test and Levene's test, respectively. NRN data were not normally distributed, so means were compared using the Mann-Whitney U-statistic.

\section{Results}

Cadaver burial resulted in a 1.4-2.2-fold increase in soil NRN (Figure 1). Significantly greater NRN was observed in Yabulu and Wambiana gravesoil within 7 days of burial. However, this increase did not occur in Pallarenda gravesoil until day 14. Once elevated, the concentration of NRN in gravesoils remained constant until the end of the experiment (day 28), by which time the cadaver had been skeletonized for a minimum of 14 days.

\section{Discussion}

The current results demonstrated that cadaver decomposition released a significant amount of NRN into associated soil. This rapid and persistent increase in NRN has great potential to become a useful investigative tool for the location of clandestine graves especially considering that, upon arrival to the laboratory, the analysis of NRN in gravesoil can be conducted in approximately $2 \mathrm{~h}$ using materials that are widely available to most crime laboratories throughout the world. However, the inclusion of this method into the standard forensic science toolkit should require the investigation of several other factors, including the effect of soil type, burial depth, cadaver mass, ambient temperature and soil moisture, the innate spatial and temporal heterogeneity of NRN, and the persistence of NRN in gravesoil.

The delayed significant increase of NRN in Pallarenda soil is probably due to the high sand content of this soil. Burial in sandy soil tends to promote desiccation rather than decomposition (19) (especially in conditions such as tropical dry seasons), which is primarily due to the increased rate of gas diffusion in sand relative to finer textured soils (i.e., silt, clay) (20). A lack of available water can retard the activity of enzymes (21) associated with the cycling of $\mathrm{N}$, as many of these are hydrolytic. Recent research $(11,22)$ demonstrated that soil type can have significant effect on cadaver decomposition in soil. This effect apparently extends to the concentration of NRN in gravesoil.

One logical avenue of future investigation is determining the time required for NRN to be released into the soil. Bodies can be moved from the original site of death (and subsequent scenes), so it is conceivable that a body in fresh stage decomposition (23) could come into contact with the soil without affecting the concentration of NRN. At a later stage of decomposition, however, a removed human may leave a persistent effect in former gravesoil. Also, the current data show that a cadaver might not immediately affect concentrations of NRN. These phenomena must be considered when using NRN as a means to locate clandestine graves and sites of death or decomposition on the soil's surface.

The current study clearly shows that a non-human cadaver can release NRN into soil. This is important, as non-human cadavers regularly die and decompose in terrestrial ecosystems (6). Thus, the presence of high concentrations of NRN in soil does not confirm the presence of a human cadaver. It simply confirms the presence of an area of elevated organic- and/or ammonium-N. Effects of cadaver mass should also be investigated. The biological load of a juvenile rat is relatively small, 

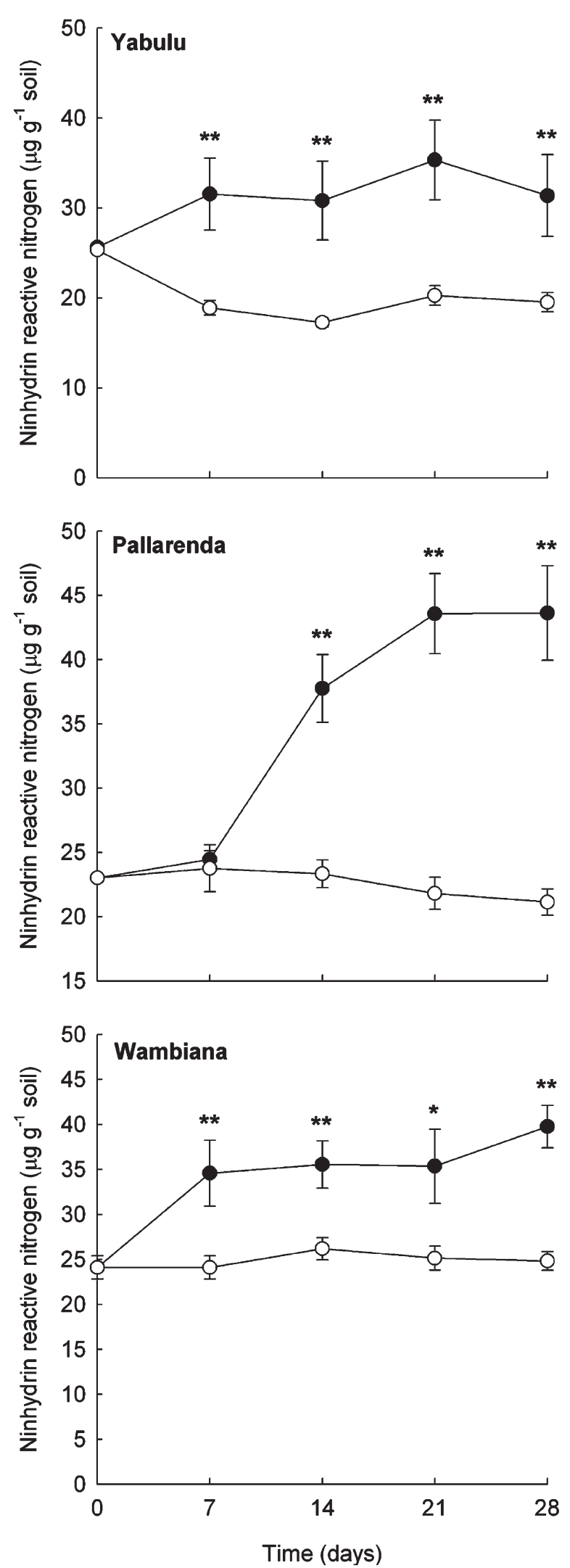

Figure 1. Concentration of ninhydrin reactive nitrogen following the burial $(2.5 \mathrm{~cm})$ of a juvenile rat (Rattus rattus) cadaver $(\bullet)$ $(\sim 20 \mathrm{~g})$ and in control ( $\circ$ : no cadaver) soil in Yabulu, Pallarenda, or Wambiana, Queensland, Australia. * represent significant differences between treatment within time where ${ }^{*}=p<0.05$ and $* *=p<0.01$. Bars represent standard errors where $n=6$. so the impact of a small mammal on soil NRN will probably be less than a large body such as a human. In addition, other organic resources, such as fecal matter and plant litter can be associated with elevated levels of NRN (24). While it is unlikely that these resources would be associated with levels of NRN as high as those found with a cadaver, it is necessary to explore these relationships in greater detail. Until this is done, or the ability to extract and identify human DNA from putative gravesoil is developed, the presence of elevated concentration of soil NRN will remain a presumptive test for gravesoil. At this stage, we view this use as being similar to the detection of acid phosphatase as a presumptive marker for semen: acid phosphatase is found in several areas of the environment, such as microorganisms (25), plants (26), and soil (27), that can come into contact with locations (e.g., clothing, genitalia) typically tested for the presence of semen.

Also requiring investigation is the lateral and vertical diffusion of NRN away from the decomposition site and burial depth. Decomposition fluids diffuse laterally and vertically away from a body (6) and we would expect a decrease in the concentration of NRN with increasing distance from a cadaver. Understanding this gradient will allow investigators to determine the proximity in which a soil sample must be collected from a body and, possibly, the spatial frequency with which putative gravesoil should be collected when searching for a clandestine grave. NRN might also be influenced by burial depth. Greater burial depth tends to result in a slower rate of cadaver decomposition, which would affect the time required for the release of NRN into gravesoil.

Further studies should investigate the persistence of NRN in gravesoil. Some aspects of chemistry can provide an accurate estimate of postmortem interval (PMI) (7) and measurement of NRN certainly holds this potential. It would be necessary to examine the concentration of NRN over time, possibly as a function of temperature, initial body mass, and soil moisture content, as conducted by Vass et al. (7). The current data show that NRN remains elevated for at least 2 weeks following skeletonization and this might have significant implications for forensic science. There is currently no one method that can accurately estimate PMI in every given circumstance. Arguably, the most accurate means to estimate PMI is through the use of entomological evidence (28), particularly after the initial $24 \mathrm{~h}$ of death when the state of the cadaver itself can be quite unpredictable. However, because this approach is best when live immature flies are collected from a scene, insects lose much of their forensic value once the initial colonizers have reached the adult stage. It is during this period, the extended PMI, that the measurement of NRN might make its most significant contribution to estimates of PMI. More detailed research is required before NRN can be used to accurately estimate PMI.

In conclusion, NRN concentrations that are approximately two times greater than control soils can represent the presence of a nitrogenous resource, probably a mammalian cadaver and possibly a human corpse. While it is unlikely that the observed reaction will ever be accepted as a confirmatory test of gravesoil, a fundamental understanding of the processes associated with gravesoils will certainly strengthen its use as a presumptive test. Future studies should investigate the effect of cadaver mass, time, clothing, burial depth, and the diffusion of NRN in soils. Once a robust understanding of these relationships is achieved, the use of ninhydrin to detect gravesoil should become recognized as a reliable contributor to the reconstruction of death scenes in terrestrial ecosystems. 
Acknowledgments - We would like to thank C. Adams, P. O'Reagain, C. Stokes, and M. Whiting for access to our study sites. We are thankful to S. Blyth for breeding the rats used in the current study. Also, we thank L. Barksdale for informative discussion prior to the preparation of this manuscript.

\section{References}

1. Preuß J, Strehler M, Dressler J, Riße M, Anders S, Madea B. Dumping after homicide using setting in concrete and/or sealing with bricks - Six case reports. Forensic Sci Int 2006; 159: 55-60.

2. Manhein M. Decomposition rates of deliberate burials: A case of preservation. In: Haglund WD, Sorg MH, editors. Forensic Taphonomy: The Postmortem Fate of Human Remains. Boca Raton, FL: CRC Press, 1997; 469-82.

3. Killam EW. The Detection of Human Remains. Springfield, IL, USA: Charles C. Thomas, 1990.

4. Lasseter AE, Jacobi KP, Farley R, Hensel L. Cadaver dog and handler team capabilities in the recovery of buried human remains in the Southeastern United States. J Forensic Sci 2003; 48: 617-21.

5. Vass AA, Smith RR, Thompson CV, Burnett MN, Wolf DA, Synstelien JA, et al. Decompositional odor analysis database. J Forensic Sci 2004; 49: 760-9.

6. Carter DO, Yellowlees D, Tibbett M. Cadaver decomposition in terrestrial ecosystems. Naturwissenschaften 2007; 94: 12-24.

7. Vass AA, Bass WM, Wolt JD, Foss JE, Ammons JT. Time since death determinations of human cadavers using soil solution. J Forensic Sci 1992; 37: 1236-53.

8. Hopkins DW, Wiltshire PEJ, Turner BD. Microbial characteristics of soils from graves: an investigation at the interface of soil microbiology and forensic science. Appl Soil Ecol 2000; 14: 283-8.

9. Carter DO, Tibbett M. Microbial decomposition of skeletal muscle tissue (Ovis aries) in a sandy loam soil at different temperatures. Soil Biol Biochem 2006; 38: 1139-45.

10. Forbes SL, Stuart BH, Dent BB. The effect of the burial method on adipocere formation. Forensic Sci Int 2005; 154: 44-52.

11. Forbes SL, Dent BB, Stuart BH. The effect of soil type on adipocere formation. Forensic Sci Int 2005; 154: 35-43.

12. Tortora GJ, Grabowski SR. Principles of Anatomy and Physiology. 9th ed. New York: John Wiley \& Sons, Inc., 2000.

13. Ruhemann S. Triketohydrindene hydrate. J Chem Soc, Trans 1910; 97: 2025-31.
14. Odén S, von Hofsten B. Detection of fingerprints by the ninhydrin reaction. Nature 1954; 173: 449-50.

15. Schwarz L, Klenke I. Enhancement of ninhydrin- or DFOtreated latent fingerprints on thermal paper. J Forensic Sci 2007; 52: 649-55.

16. Isbell RF. The Australian Soil Classification. Collingwood: CSIRO Publishing, 2002.

17. Tibbett M, Carter DO, Haslam T, Major R, Haslam R. A laboratory incubation method for determining the rate of microbiological degradation of skeletal muscle tissue in soil. $J$ Forensic Sci 2004; 49: 560-5.

18. Amato M, Ladd JN. An assay for microbial biomass based on ninhydrin-reactive nitrogen in extracts of fumigated soils. Soil Biol Biochem 1988; 20: 107-14.

19. Aufderheide AC. Soft tissue palaeopathology - An emerging subspecialty. Hum Pathol 1981; 12: 865-7.

20. Hillel D. Environmental Soil Physics. San Diego, CA: Academic Press, 1998.

21. Skujins JJ, McLaren AD. Enzyme reaction rates at limited water activities. Science 1967; 158: 1569-70.

22. Fiedler S, Schneckenberg K, Graw M. Characterization of soils containing adipocere. Arch Environ Contam Toxicol 2004; 47: 561-8.

23. Megyesi MS, Nawrocki SP, Haskell NH. Using accumulated degree-days to estimate the postmortem interval from decomposed human remains. J Forensic Sci 2005; 50: 618-26.

24. Ocio JA, Brookes PC, Jenkinson DS. Field incorporation of straw and its effects on soil microbial biomass and soil inorganic N. Soil Biol Biochem 1991; 23: 171-6.

25. Tibbett M, Sanders FE, Cairney JWG. The effect of temperature and inorganic phosphorus supply on growth and acid phosphatase production in arctic and temperate strains of ectomycorrhizal Hebeloma spp. in axenic culture. Mycol Res 1998; 102: 129-35.

26. Tadano T, Ozowa K, Satai M, Osaki M, Matsui H. Secretion of acid phosphatase by the roots of crop plants under phosphorus-deficient conditions and some properties of the enzyme secreted by lupin roots. Plant Soil 1993; 144: 167-76.

27. Klose S, Tabatabai MA. Response of phosphomonoesterases in soils to chloroform fumigation. J Plant Nutrition Soil Sci 2002; 165: 429-34.

28. Nabity PD, Higley LG, Heng-Moss TM. Effects of temperature on development of Phormia regina (Diptera: Calliphoridae) and use of developmental data in determining time intervals in forensic entomology. J Med Entomol 2006; 43: 1276-86. 